\title{
Presurgical epilepsy evaluation and epilepsy surgery [version
}

\section{1; peer review: 2 approved]}

\section{Christoph Baumgartner (D1-3, Johannes P. Koren 1,2, Martha Britto-Arias ${ }^{1,2}$, Lea Zoche ${ }^{1,2}$, Susanne Pirker ${ }^{1,2}$}

\author{
${ }^{1}$ Department of Neurology, General Hospital Hietzing with Neurological Center Rosenhügel, Vienna, Austria \\ ${ }^{2}$ Karl Landsteiner Institute for Clinical Epilepsy Research and Cognitive Neurology, Vienna, Austria \\ ${ }^{3}$ Medical Faculty, Sigmund Freud University, Vienna, Austria
}

V1 First published: 29 Oct 2019, 8(F1000 Faculty Rev):1818

https://doi.org/10.12688/f1000research.17714.1

Latest published: 29 Oct 2019, 8(F1000 Faculty Rev):1818

https://doi.org/10.12688/f1000research.17714.1

\section{Abstract}

With a prevalence of 0.8 to $1.2 \%$, epilepsy represents one of the most frequent chronic neurological disorders; 30 to $40 \%$ of patients suffer from drug-resistant epilepsy (that is, seizures cannot be controlled adequately with antiepileptic drugs). Epilepsy surgery represents a valuable treatment option for 10 to $50 \%$ of these patients. Epilepsy surgery aims to control seizures by resection of the epileptogenic tissue while avoiding neuropsychological and other neurological deficits by sparing essential brain areas. The most common histopathological findings in epilepsy surgery specimens are hippocampal sclerosis in adults and focal cortical dysplasia in children. Whereas presurgical evaluations and surgeries in patients with mesial temporal sclerosis and benign tumors recently decreased in most centers, non-lesional patients, patients requiring intracranial recordings, and neocortical resections increased. Recent developments in neurophysiological techniques (high-density electroencephalography [EEG], magnetoencephalography, electrical and magnetic source imaging, EEG-functional magnetic resonance imaging [EEG-fMRI], and recording of pathological high-frequency oscillations), structural magnetic resonance imaging (MRI) (ultra-highfield imaging at 7 Tesla, novel imaging acquisition protocols, and advanced image analysis [post-processing] techniques), functional imaging (positron emission tomography and single-photon emission computed tomography co-registered to MRI), and fMRI significantly improved non-invasive presurgical evaluation and have opened the option of epilepsy surgery to patients previously not considered surgical candidates. Technical improvements of resective surgery techniques facilitate successful and safe operations in highly delicate brain areas like the perisylvian area in operculoinsular epilepsy. Novel less-invasive surgical techniques include stereotactic radiosurgery, MR-guided laser interstitial thermal therapy, and stereotactic intracerebral EEG-guided radiofrequency thermocoagulation.

\section{Open Peer Review}

Approval Status

\section{1}

version 1

29 Oct 2019

Faculty Reviews are review articles written by the prestigious Members of Faculty Opinions. The articles are commissioned and peer reviewed before publication to ensure that the final, published version is comprehensive and accessible. The reviewers who approved the final version are listed with their names and affiliations.

1. Daniel L Drane, Emory University School of Medicine, Atlanta, USA

University of Washington School of Medicine, Seattle, USA

2. Pieter van Mierlo, Ghent University, Ghent, Belgium

Any comments on the article can be found at the end of the article. 
Keywords

epilepsy, surgery, presurgical evaluation

Corresponding author: Christoph Baumgartner (cs.baumgartner@gmail.com)

Author roles: Baumgartner C: Conceptualization, Data Curation, Formal Analysis, Investigation, Methodology, Project Administration, Resources, Supervision, Validation, Visualization, Writing - Original Draft Preparation; Koren JP: Writing - Review \& Editing; Britto-Arias M: Writing - Review \& Editing; Zoche L: Writing - Review \& Editing; Pirker S: Writing - Review \& Editing

Competing interests: No competing interests were disclosed.

Grant information: The author(s) declared that no grants were involved in supporting this work.

Copyright: ( 2019 Baumgartner C et al. This is an open access article distributed under the terms of the Creative Commons Attribution License, which permits unrestricted use, distribution, and reproduction in any medium, provided the original work is properly cited.

How to cite this article: Baumgartner C, Koren JP, Britto-Arias M et al. Presurgical epilepsy evaluation and epilepsy surgery [version 1; peer review: 2 approved] F1000Research 2019, 8(F1000 Faculty Rev):1818 https://doi.org/10.12688/f1000research.17714.1

First published: 29 Oct 2019, 8(F1000 Faculty Rev):1818 https://doi.org/10.12688/f1000research.17714.1 


\section{Introduction}

Epilepsy has a prevalence of 0.8 to $1.2 \%$ and thus represents one of the most frequent chronic neurological disorders ${ }^{1,2}$. In about 30 to $40 \%$ of patients, seizures cannot be controlled adequately with antiepileptic drugs; that is, these patients suffer from drug-resistant epilepsy ${ }^{3,4}$. Epilepsy surgery represents a valuable treatment option for 10 to $50 \%$ of these patients ${ }^{4}$ and has been shown to be significantly superior to continued antiepileptic drug treatment regarding seizure control and quality of life in both children and adults ${ }^{5-7}$. The goals of epilepsy surgery are seizure control by resection of the epileptogenic tissue on the one hand while sparing essential brain areas to avoid neuropsychological and other neurological deficits on the other hand ${ }^{3,4,8-10}$. This can be achieved only by a thorough presurgical evaluation clearly delineating epileptogenic and essential brain areas and by defining selective resection strategies in each individual patient ${ }^{3,8-10}$. Several excellent articles recently reviewed presurgical evaluation and surgical treatment of patients with drug-resistant epilepsy ${ }^{3,4,8-10}$. Here, we will focus on some selected recent developments, but we make no claim of providing an exhaustive review.

\section{Trends in presurgical evaluation and surgical treatment in the last few decades}

Blumcke et al. ${ }^{11}$ reported the largest series of histopathological findings of resected brain tissue. The tissue in this series was obtained from 9523 patients who underwent epilepsy surgery for drug-resistant epilepsy in 36 European centers between 1990 and 2014. The most common pathologies were hippocampal sclerosis (36.4\%), tumors (mainly ganglioglioma; 23.6\%), and malformations of cortical development $(19.8 \%)$. No histopathological diagnosis could be established in $7.7 \%$. Whereas the most common diagnosis in adults was hippocampal sclerosis $(44.5 \%)$, focal cortical dysplasia represented the most prevalent finding in children $(39.3 \%)$. Several significant changes in patients undergoing presurgical evaluation and epilepsy surgery occurred in the last few decades ${ }^{12-18}$. Whereas presurgical evaluations continually increased over time, surgical interventions remained stable or decreased in recent years, resulting in an increasing number of evaluated patients ultimately not undergoing surgery ${ }^{18,19}$. Specifically, the number of patients with mesial temporal sclerosis and benign tumors who were evaluated and ultimately underwent surgery decreased over time in most centers. The same holds true for the number of temporal lobe resections in general ${ }^{16,18}$. Reasons for the decrease of mesial temporal epilepsy surgery are intensively debated and could be explained by a decreasing incidence of Ammon's horn sclerosis, by a reduction of the prevalent pool, or by alternative treatment options available for these patients ${ }^{15,19-21}$. On the contrary, non-lesional patients, patients requiring intracranial recordings, and neocortical resections increased ${ }^{16,18}$. Furthermore, more evaluated patients did not undergo surgery since patients were not suitable for surgery (a circumstance due mainly to missing identification of a circumscribed epileptogenic zone) or since more patients offered surgery by physicians opted against $\mathrm{it}^{18}$. Finally, in some centers, an increase in patients willing to undergo less-invasive surgeries-for example, stereotactic radiosurgery, magnetic resonance (MR)-guided laser interstitial thermal therapy, stereotactic intracerebral electroencephalography (SEEG)-guided radiofrequency thermocoagulation (RFTC), deep brain stimulation (DBS), and responsive neurostimulation (RNS)—who had previously refused open surgery can be observed ${ }^{22}$.

\section{Presurgical evaluation - general issues}

Each presurgical evaluation starts with a so-called phase 1 evaluation. Investigations required in all patients include highresolution MR imaging (MRI), video scalp electroencephalography (EEG), and detailed neuropsychological assessment ${ }^{8,23}$.

If these investigations yield converging evidence on the localization of the epileptogenic zone and provide sufficient information on the risk of potential postoperative deficits, the patient may be referred to surgery directly.

If there are ambiguous results concerning localization of the epileptogenic zone, the following additional phase 1 investigations can be applied ${ }^{8,24}$ :

- advanced structural imaging techniques for detection of epileptogenic lesions on MRI;

- interictal high-resolution EEG (HD-EEG), interictal magnetoencephalography (MEG), interictal electrical source imaging (ESI), interictal magnetic source imaging (MSI), and interictal EEG-functional MRI (EEG-fMRI) for accurate delineation of the irritative zone ${ }^{25}$;

- interictal 18F-fluoro-deoxyglucose (FDG) positron emission tomography (PET) or interictal PET with other tracers to localize the functional deficit zone;

- ictal single-photon emission computed tomography (SPECT), ictal HD-EEG, ictal ESI, and in selected cases ictal MSI and ictal EEG-fMRI to localize the ictal onset zone.

Depending on the lateralization and localization of the planned resection, the risk of potential postoperative deficits can be further clarified by the following complementary phase 1 investigations ${ }^{8}$ :

- fMRI, MEG, and Wada test for lateralization and localization of language functions;

- fMRI and Wada test for prediction of postoperative memory decline;

- tractography of Meyer's loop and visual field testing to assess the risk of postoperative visual field defects;

- fMRI and tractography of pyramidal tract to assess the risk of postoperative motor deficits.

Although most centers agree on the essential methods of phase 1 evaluation (that is, high-resolution MRI, video scalp EEG, and detailed neuropsychological assessment), there is a lot of variability across the international community, and some 
routinely require procedures (for example, PET, SPECT, and MEG) that others may relegate to later stages of the evaluation. If the epileptogenic zone cannot be localized with sufficient certainty with these non-invasive techniques, if non-invasive techniques yield divergent results and/or if the presumed epileptogenic zone is located in close proximity to functionally important brain areas and the patient is still considered a reasonable surgical candidate, intracranial EEG (IEEG) can be applied during a so-called phase 2 evaluation ${ }^{8,24-26}$.

Chronic extraoperative IEEG techniques include the following: - extraoperative IEEG through open craniotomy (CEEG); after the open craniotomy, subdural grids or strips or a combination of depth electrodes and subdural electrodes are placed under direct observation;

- SEEG using intracerebral depth electrodes; usually 5-18 multicontact electrodes are inserted through a twist drill hole or burr hole under general anesthesia. The electrodes are placed stereotactically with a frame, under neuronavigational guidance, or, robotic assistance. The trajectories of the electrodes have to be planned thoroughly to avoid crossing blood vessels;

- hybrid extraoperative EEG (HEEG) consisting of a hybrid of CEEG and SEEG;

- foramen ovale IEEG with multicontact electrodes placed to lie along the long axis of the hippocampus (usually bilaterally);

- epidural IEEG using epidural peg electrodes, allowing sampling from several cortical areas, even distant ones ${ }^{26}$.

It should be mentioned that in many centers there has been a shift from CEEG to SEEG, which is less invasive and much more comfortable for patients. Ideally, the modality best suited for each individual patient should be applied in accordance with standardized protocols ${ }^{26}$.

Intraoperative electrocorticography (ECoG) where IEEG recordings and electrical stimulation mapping (ESM) are performed intraoperatively prior to, during, and often following resection using subdural, depth, or wick electrodes placed under direct visualization or guided by neuronavigation represents an additional option, especially in patients with cortical dysplasia, tuberous sclerosis, or scalp EEG with continuous epileptiform discharges (CEDs), when extraoperative intracranial EEG is not feasible and finally when surgery is performed adjacent to language or motor cortex ${ }^{25}$. The diagnostic utility, strengths and limitations, risks/morbidities, and specific indications of various IEEG techniques were summarized in a consensus-based expert recommendation ${ }^{26}$.

\section{Neurophysiological techniques}

Recent advances in clinical neurophysiology include localization of the irritative zone (that is, the interictal spike zone with ESI, MSI, and EEG-fMRI). ESI and MSI represent biophysical models which allow us to calculate from the EEG resp. MEG signals measured on the scalp the intracerebral neuronal sources generating these signals, that is solving the so-called inverse problem of clinical neurophysiology $y^{27,28}$. Localization accuracy and sensitivity of EEG can be significantly improved when the number of electrodes is increased beyond the standard 10-20 system $^{29}$ and when montages sampling inferior temporal areas with electrodes around and below the ears and on the cheeks and neck are used ${ }^{30,31}$. HD-EEG set-ups currently use 128 to 256 EEG electrodes ${ }^{32,33}$. In a study comparing various non-invasive techniques (that is, structural MRI, HD-ESI, PET, and SPECT), the combination of MRI and HD-ESI offered the highest predictive value for postoperative seizure freedom ${ }^{34}$. The sensitivity of MEG for the detection of interictal spikes on ECoG was assessed in a study using simultaneous MEG and ECoG recordings ${ }^{35}$. Of all of the interictal ECoG spikes, 56\% had an interictal MEG counterpart. The rates of association between MEG and ECoG were at least $90 \%$ in the interhemispheric and frontal orbital regions; about $75 \%$ in the superior frontal, central, and lateral temporal regions; but only about $25 \%$ in the mesial temporal region ${ }^{35}$. Recently, spectral and functional connectivity properties of non-invasively obtained HD-EEG and MEG virtual electrodes matched those of SEEG recordings. HD-EEG and MEG virtual electrodes therefore might be used for optimal SEEG planning, making the localization of the seizure onset zone safer and more successful $^{36}$. The yield of simultaneous scalp EEG-fMRI studies (40 to $70 \%$ of recordings remain inconclusive and this is due principally to the absence of interictal epileptiform discharges during simultaneous recordings or lack of hemodynamic changes correlated to interictal epileptiform discharges) can be significantly increased by building epilepsy-specific electroencephalographic voltage maps using averaged interictal epileptiform discharges recorded during long-term clinical monitoring outside the scanner, computing the correlation of these maps with EEG recordings in the scanner for each time frame, and using the time course of this correlation coefficient as a regressor for fMRI analysis to map hemodynamic changes related to these epilepsy-specific maps (topography-related hemodynamic changes $)^{37}$. With this technique, scalp EEGfMRI results can be obtained even in the absence of visually detectable spikes during the EEG-fMRI $\operatorname{session}^{37}$. In a recent study in 53 children including MRI-negative cases, the combination of EEG-fMRI with ESI could localize the seizure onset zone with high accuracy and predicted surgical outcome in all patients ${ }^{38}$.

Localizations obtained by interictal ESI, MSI, and EEGfMRI showed excellent agreement both with the irritative zone delineated by intracranial electrodes and with the epileptogenic zone defined by other investigations ${ }^{32,35,36,39,40}$. Furthermore, complete resection of the irritative zone defined by these methods resulted in a favorable surgical outcome $\mathrm{e}^{32,38,39,41}$.

Recently, ictal ESI was successfully applied for localization of the ictal onset zone ${ }^{42-50}$. Ictal MSI is also feasible but is limited by the fact that long-term MEG recordings cannot be performed and it remains difficult to catch seizures during short-term MEG recordings ${ }^{51-54}$. 
It should be noted that automated techniques exist to perform both interictal and ictal $\mathrm{ESI}^{25,42}$.

Pathological high-frequency oscillations (pHFOs) in the frequency range of 100 to $600 \mathrm{~Hz}$ are considered biomarkers of epileptogenic tissue ${ }^{55-58}$. It could be shown that pHFOs, while initially recorded only on invasive EEG, can also be recorded non-invasively on scalp EEG and $\mathrm{MEG}^{57,59-62}$. pHFOs are of high localizing significance, and removal of brain areas generating pHFOs predicts a favorable postsurgical seizure control $^{57,63-65}$. Recently, it was shown that $\mathrm{pHFO}$ activity may change during surgery and that removal of post-resection pHFO can further improve surgical outcome ${ }^{66}$. However, the added value of pHFOs compared with interictal spikes is still discussed in the community and combined measures of spikes and pHFOs might improve identification of epileptogenic tissue ${ }^{67}$.

Cortico-cortical evoked potentials (CCEPs) in conjunction with neuroimaging techniques like diffusion tensor imaging (DTI) have recently been successfully applied to identify both epileptogenic and functional networks ${ }^{68-72}$.

\section{Structural neuroimaging}

Progress in structural neuroimaging has revolutionized presurgical epilepsy evaluation in recent years ${ }^{73-75}$. Structural neuroimaging aims to identify an epileptogenic lesion responsible for the patient's seizures which in turn significantly increases the chances of postoperative seizure freedom ${ }^{76,77}$. However, 15 to $30 \%$ of patients with drug-resistant epilepsy remain MRInegative; that is, no structural lesion can be identified ${ }^{73,78,79}$. A widely accepted imaging protocol for epilepsy-specific imaging based on six sequences could identify $99.4 \%$ of 2740 epileptogenic lesions and provides a reasonable balance between diagnostic accuracy and clinical feasibility ${ }^{80}$. This protocol includes 3D volumetric T1-weighted imaging (1-mm isotropic voxels) (detection of malformations of cortical development and application of post-processing techniques), axial and coronal T2-weighted (T2/short tau inversion recovery [STIR]) imaging (assessment of hippocampal architecture and cystic tissue components of other lesions), axial and coronal fluid-attenuated inversion recovery (FLAIR) sequences (detection of hippocampal sclerosis, focal cortical dysplasia, tumors, inflammation, and scars), and axial $\mathrm{T} 2 *$ gradient echo or susceptibilityweighted (Hemo/Calc) sequences (identification of vascular and calcified lesions such as cavernomas and arteriovenous malformations) $)^{73,80}$.

The detection of lesions, especially of focal cortical dysplasia and hippocampal sclerosis, can be significantly increased by improvements of imaging hardware (including ultra-high-field imaging at 7 Tesla), by novel imaging acquisition protocols, and by advanced image analysis (post-processing) techniques ${ }^{73}$.

Ultra-high-field imaging at 7-Tesla MRI in patients with hippocampal sclerosis showed a strong correlation between MRI and histology with sensitivity and specificity values up to $100 \%$ for the detection of pathology in various hippocampal subfields $^{81}$. Seven-Tesla MRI including whole-brain FLAIR and gradient-recalled echo (GRE) images could detect epileptogenic focal cortical dysplasia not visible at conventional field strengths in a third of cases, while gliosis remained undetected ${ }^{82}$.

Advances in imaging acquisition protocols can be useful to detect lesions which cannot be identified by using routine imaging protocols $\mathrm{s}^{73}$. Double inversion recovery suppresses the signals from both cerebrospinal fluid (CSF) and normal white matter and therefore enhances the detection of cortical lesions otherwise masked by white matter or CSF signal ${ }^{83}$. Arterial spin labeling provides a quantitative measure of regional cerebral blood flow $(\mathrm{rCBF})$ and demonstrated a reduced regional perfusion in the seizure onset zone - in good agreement with hypometabolism on PET - in MRI-negative patients ${ }^{84}$. Neurite orientation dispersion and density imaging (NODDI) represents an advanced diffusion imaging technique that provides more detailed information on tissue microstructure, including intracellular volume fraction, a marker of neurite density, and was helpful to identify focal cortical dysplasia in MRI-negative patients ${ }^{85}$

Several post-processing methods, including voxel-based morphometry, T2-relaxometry, surface-based morphometry, or DTI recently combined with machine learning approaches, can be useful for the identification of lesions not apparent on visual MRI analysis ${ }^{73,74,86-94}$.

\section{Neuropsychological assessment}

Cognitive impairments in epilepsy can be caused by underlying pathology, seizures, interictal spikes, antiepileptic drugs, and psychiatric comorbidities ${ }^{95}$. Although neuropsychological assessment remains an essential investigation during presurgical evaluation, the advent of high-resolution structural and functional brain imaging as well as sophisticated EEG analysis techniques has shifted the main focus of neuropsychology from localization toward prediction of postsurgical cognitive outcome and quality control of epilepsy surgery ${ }^{95-97}$. The major factors determining postsurgical neuropsychological performance include functional integrity of the resected tissue, functional reserve capacity of the remaining brain, the degree of functional plasticity, postoperative control of epileptic activity, and the effects of quantitative and qualitative postsurgical antiepileptic drug changes ${ }^{10,97-99}$. However, it is still not possible to predict with certainty which patient will experience disabling functional loss on an individual scale ${ }^{100}$. Several studies showed stable or even improved long-term postsurgical cognitive outcomes, especially in seizure-free patients ${ }^{101-103}$. In regard to cognitive outcomes of different surgical approaches, individual and selective surgery preserving functional brain tissue and fiber tracts, thus minimizing collateral damage, should be preferred ${ }^{104}$. Although radiosurgery or thermocoagulation should be advantageous from this perspective, no clear scientific evidence of a superior cognitive outcome of these procedures compared with conventional open surgery currently exists ${ }^{98}$. Recommendations for a standardized neuropsychological assessment in the preoperative evaluation and postoperative follow-up of epilepsy surgery patients have been published by the International League 
Against Epilepsy (ILAE) Neuropsychology Task Force Diagnostic Methods Commission ${ }^{105,106}$. Neuropsychological assessments of patients undergoing MRI-guided stereotactic laser amygdalohippocampectomy resulting in very small focal lesions showed outcomes not consistent with prevailing models of brain function. Thus, the hippocampus does not appear to be an essential component of neural networks underlying naming, verbal fluency, object and person recognition, and declarative verbal memory ${ }^{107,108}$. Furthermore, white matter tracts have been proven to be crucial for language and semantic networks. The basal temporal language area is likely a critical hub in the language network ${ }^{109}$. Therefore, MRI-guided stereotactic laser amygdalohippocampectomy offers a unique opportunity to study structure-function brain relationships and to reappraise many of our models of cognitive networks ${ }^{107}$. Moreover, traditional neuropsychological assessment does not include many cognitive domains of potentially high clinical relevance, including category-specific naming and fluency as well as object and face recognition, for epilepsy patients in their everyday lives ${ }^{110}$. Future neuropsychological testing should integrate sensory and linguistic/semantic information with the existing knowledge of the patient, explore memory consolidation over long periods of time, and attempt to relate cognition to features of signal processing in order to better assess cognitive networks and to provide objective measures accounting for subjective cognitive complaints of the patients ${ }^{110}$.

\section{Positron emission tomography and single-photon emission computed tomography}

The role of PET and SPECT in presurgical evaluation was recently reviewed by several authors ${ }^{8,73,74,111}$. FDG-PET assessing interictal brain dysfunction (that is, the functional deficit zone) has been used during presurgical evaluation for more than 35 years $^{112}$. In mesial temporal lobe epilepsy (MTLE), FDGPET shows a widespread ipsilateral hypometabolism involving the temporal lobe (that is, mesial temporal structures, temporal pole, and lateral temporal cortex) as well as extratemporal areas (including the insula, the frontal lobe, perisylvian regions, and the thalamus). This hypometabolism is more pronounced in right as compared with left MTLE $^{113}$. The topography of hypometabolism on PET showed a strong correlation with the extent of the electroclinical network defined by clinical seizure semiology and $\mathrm{EEG}^{113}$. Homotopic contralateral hypermetabolism indicating possible compensatory mechanisms was relatively higher in patients with left-sided MTLE and in female patients but was lower with longer disease duration, later onset of epilepsy, and higher seizure frequency ${ }^{113}$. These findings indicate that MTLE is not a focal but rather a network disease that can affect interconnected and even distant brain areas $^{114,115}$. Hypometabolic patterns on FDG-PET were predictive for surgical outcome in patients with MTLE ${ }^{116,117}$. Specifically, non-class IA outcome correlated with extratemporal metabolic changes whereas class IA outcome was associated with a focal anteromesial temporal hypometabolism ${ }^{116}$.

In MRI-negative temporal lobe epilepsy (TLE), a hypometabolism ipsilateral to the presumed epileptogenic zone is a predictor for a favorable surgical outcome ${ }^{118}$. Thus, in patients with
MRI-negative FDG-PET-positive TLE, an excellent surgical outcome can be achieved after anterior temporal lobectomy (and this is very similar to the outcome in patients with hippocampal sclerosis on MRI ${ }^{119-121}$. These patients probably do not need to undergo intracranial recordings, especially if seizures arise from the non-dominant temporal lobe ${ }^{120,121}$.

In MRI-negative extratemporal lobe epilepsy (ETLE), FDGPET co-registered with MRI is highly sensitive to detect focal cortical dysplasia and thus significantly improves diagnosis and surgical outcome of these patients ${ }^{122}$. In a recent series of patients with histologically proven focal cortical dysplasia type 2 with negative or doubtful MRI, FDG-PET co-registered with MRI correctly localized the focal cortical dysplasia in $83 \%$ of patients, resulting in excellent surgical outcome after limited resections (seizure-free outcome in $94 \%$ of patients and Engel class IA in $72 \%)^{123}$. Automated easy-to-use quantification of FDG PET-computed tomography was clearly superior to visual analysis for the identification of the epileptogenic zone in patients with probable frontal cortical dysplasia (concordance for automated quantification $72.7 \%$ versus $22.7 \%$ for visual analysis) ${ }^{124}$. Recently, machine learning approaches using a classifier based on optimized cortical surface sampling of combined MRI and PET features were superior to both quantitative MRI and multimodal visual analysis for the detection of focal cortical dysplasia (93\% versus $82 \%$ versus $68 \%)^{125}$.

Ictal SPECT provides information on changes of $\mathrm{rCBF}-$ which is considered a surrogate marker of increased neuronal activity-in the seizure onset zone. Ictal SPECT is applied primarily in MRI-negative extratemporal cases or in patients with discordant findings from other investigations ${ }^{74}$. The sensitivity and specificity of visual ictal SPECT interpretation (that is, visual comparison of ictal and interictal studies) can be significantly improved by subtraction SPECT co-registered to MRI (SISCOM) (that is, subtracting interictal from ictal SPECT with co-registration to MRI ${ }^{126}$. However, a major limitation of SISCOM is that normal physiologic variations between scans cannot be accounted for ${ }^{127}$. Statistical parametric mapping (SPM)-based methods using a normal database can identify changes in $\mathrm{rCBF}$ which are statistically significantly different from normal on a voxel-by-voxel basis. One of these methods-statistical ictal SPECT co-registered to MRI (STATISCOM)-was superior to SISCOM in patients with TLE ${ }^{128}$. Recently, a commercially available and easy-to-use software package (MIMneuro, MIM Software Inc., Cleveland, $\mathrm{OH}$, USA) became available for ictal/interictal SPECT and MRI analysis. In a recent article, these three methods were systematically compared ${ }^{127}$. STATISCOM, closely followed by MIMneuro, showed the best performance for seizure localization, and both were superior to SISCOM ${ }^{127}$.

\section{Functional magnetic resonance imaging}

fMRI is used mainly for localization of eloquent cortex and to predict postoperative language as well as memory outcomes $^{8,73,74}$. Recently, the American Academy of Neurology (AAN), in a practice guideline, assessed diagnostic accuracy and prognostic value of fMRI in determining lateralization and predicting postsurgical language and memory outcomes ${ }^{129}$. 
The authors performed a meta-analysis and concluded that language lateralization based on fMRI was concordant with the Wada test in MTLE (concordance rate of 87\%) and in ETLE (concordance rate of $81 \%$ ) but that data were insufficient for temporal tumors or lateral temporal cases $^{129}$. Indeed, fMRI has replaced the Wada test for language lateralization in many centers $^{73,74}$. According to the practice guideline, fMRI is possibly effective to predict postsurgical language deficits in patients undergoing temporal lobectomy ${ }^{129}$. A stronger left temporal activation during a semantic decision task predicted a greater postoperative naming decline with a sensitivity of $100 \%$, a specificity of $73 \%$, and a positive predictive value of $81 \%$ and was superior to the predictive value of the Wada test (sensitivity of $92 \%$, specificity of $45 \%$, and positive predictive value of $67 \%)^{130}$. In patients with left TLE, left frontal MRI activation during a verbal fluency task predicted a postoperative decline in verbal naming after left temporal lobe resections with good sensitivity (100\%) but poor specificity (33\%) and a positive predictive value of $60 \%^{131}$. Auditory and visual naming tasks eliciting anterior temporal activations are more related to naming and can provide more consistent predictive values with higher specificity ${ }^{132}$. A recent machine learning study used a support vector regression (SVR) model and the results of multimodal presurgical language mapping, including fMRI, MEG, transcranial magnetic stimulation, and highgamma ECoG (hgECoG), to predict postoperative language outcome. The SVR model consisting of fMRI and MEG was the optimal model that facilitated the best trade-off between model complexity and prediction accuracy ${ }^{133}$.

In regard to language localization in patients with resections close to language cortex, cortical stimulation mapping from chronically indwelling electrodes or during awake craniotomy is generally considered the necessary gold standard ${ }^{73,134}$. However, in a recent study in patients with frontal lobe epilepsy, a significant postoperative naming decline was observed when the resection overlapped with language fMRI activation, even when electrocortical stimulation results were negative for language function in these areas ${ }^{135}$. These findings support the role of fMRI for presurgical language localization ${ }^{74}$.

In patients with TLE, re-organization of memory-encoding networks involves both ipsi- and contra-lateral temporal but also extratemporal brain areas ${ }^{136}$. Furthermore, dynamic postoperative changes of these networks occur after left and right temporal lobe resections in both verbal and visual domains ${ }^{137}$. Specifically, the contralateral hippocampus influences memory outcome 12 months after surgery ${ }^{137}$. The AAN practice guideline recommended memory fMRI to lateralize and predict verbal and non-verbal memory outcome after temporal lobe surgery ${ }^{129}$. In left TLE, left anterior hippocampal but also left frontal fMRI activation during verbal encoding correlated significantly with greater verbal memory decline after left anterior temporal lobe resections while ipsilateral posterior hippocampal activation was associated with better postoperative verbal memory outcome ${ }^{138,139}$. In right TLE, predominantly right anterior hippocampal activation during face encoding was predictive of a greater decline of visual memory after right anterior temporal lobe resection while predominantly right-sided posterior hippocampal activation correlated with better postoperative visual memory ${ }^{138}$. In a recent study, lateralization of memory fMRI activations using a picture recognition paradigm predicted postoperative verbal and visual memory outcome independent of the type of lesion, the side of the epileptic focus, or the type of preoperative memory profile (typical or atypical) $^{140}$.

Nevertheless, it should be mentioned that, during presurgical epilepsy evaluation in a clinical setting, correct and clinically useful interpretation of fMRI strongly depends on the individual investigator's and center's expertise. Indeed, the authors of the AAN practice guideline stated that there is still a great need for further research in this area and that clinicians should carefully advise patients of the risks and benefits of fMRI versus Wada test during discussions concerning the choice of a specific modality in each individual case ${ }^{129}$. In conclusion, both the Wada test and fMRI have their specific indications and limitations.

\section{Surgical techniques}

Resective epilepsy surgery is still primarily lesion-directed because complete resection of an epileptogenic lesion represents the major determinant for a favorable surgical outcome ${ }^{8}$. In non-lesional TLE, surgery can be performed on the basis of noninvasive phase 1 investigations, especially if seizures arise from the non-dominant hemisphere. On the contrary, in non-lesional extratemporal epilepsies, resections have to rely on an exact delineation of the electro-clinically defined seizure onset zone by intracranial recordings ${ }^{26,141}$.

Epilepsy surgeries requiring an operculoinsulectomy pose significant difficulties because the perisylvian area is highly vascular, deep, and functional. Recently, successful surgical treatment of operculoinsular epilepsy (Engel class I seizure control in $80 \%$ of patients) with an acceptable long-term complication rate was reported ${ }^{142}$.

Novel surgical techniques in clinical use include stereotactic radiosurgery, MR-guided laser interstitial thermal therapy (MgLiTT), and SEEG-guided RFTC ${ }^{8,10}$.

A 2016 meta-analysis on stereotactic radiosurgery in TLE including 13 studies showed a pooled seizure-free rate of $50.9 \%$ (with a significant heterogeneity between studies ranging from 0 to $86 \%)^{143}$. The most frequent adverse events were visual field deficits, headache, and verbal memory impairment ${ }^{143}$. A systematic review and practice guideline of the International Stereotactic Radiosurgery Society concluded that radiosurgery was effective to control seizures in MTLE (possibly with better neuropsychological outcomes and quality-of-life metrics in selected subjects compared with microsurgery) and that radiosurgery had a better risk-benefit ratio for small hypothalamic hamartomas compared with surgical methods. However, the delayed therapeutic effect with ongoing seizures carries significant morbidity and mortality risks. For other indications, including corpus callosotomy, cavernomas 
malformations, and ETLE, evidence was insufficient to make recommendations ${ }^{144}$.

MgLiTT entails the focused application of thermal energy in the form of intense light to tissue anywhere within the intracranial space in conjunction with real-time MR thermography, which is used to monitor the delivery of this energy producing a 5- to 20-mm-diameter ablation zone ${ }^{145}$. MgLiTT has been used for the treatment of various epileptogenic conditions, including MTLE, hypothalamic hamartomas, periventricular nodular heterotopia, tuberous sclerosis, cortical dysplasia, cavernous hemangiomas, and insular encephalomalacia ${ }^{166,147}$. In MTLE, seizure outcome was similar to or slightly worse than that of open surgery while cognitive outcome was better ${ }^{107,108,145,147-150}$. In a series of 71 hypothalamic hamartoma patients operated with MgLiTT, 93\% were free of gelastic seizures at one year. One patient experienced a significant memory deficit, and one patient experienced worsening diabetes insipidus. Thus, MgLiTT represents a safe and effective surgical option for the treatment of hypothalamic hamartomas ${ }^{151}$. Advantages of MgLiTT include its minimally invasiveness with better tolerability and quicker recovery time, fewer major complications, possibly a lower degree of adverse cognitive effects and the fact that it can be repeated and does not preclude subsequent surgery ${ }^{10,147}$.

Total or partial destruction of the epileptogenic zone as tailored to each patient by SEEG exploration is the goal of SEEG-guided RFTC. A radiofrequency generator connected to the electrode contacts is used to produce multiple SEEG-guided RFTC lesions of epileptic foci ${ }^{152}$. SEEG-guided RFTC has been performed in hippocampal sclerosis, periventricular nodular heterotopias, focal cortical dysplasia, tuberous sclerosis and in patients with normal $\mathrm{MRI}^{152-160}$. According to a recent review, seizure-free rate was rather heterogeneous across studies with a pooled seizure-free rate of $23 \%$ and a pooled responder rate of $58 \%{ }^{159}$. The highest responder rate was observed in patients with nodular heterotopia, the lowest in patients with normal MRI. The pooled rate of permanent neurologic deficit was $2.5 \%$. The authors concluded that SEEG-guided RFTC represents a safe treatment for patients with drug-resistant focal epilepsy when conventional resective surgery is not feasible ${ }^{159}$.

In a significant number of patients with medically refractory epilepsy, curative epilepsy surgery cannot be offered since there are multiple epileptogenic zones, the epileptogenic zone cannot be localized at all, or the epileptogenic zone is located within functionally relevant brain areas. For these patients, various neurostimulation techniques, including vagus nerve stimulation (VNS), DBS, and RNS, are becoming an increasingly accepted treatment option and therefore should be considered in every patient with medically refractory epilepsy who is unsuitable for surgery ${ }^{161}$. However, in contrast to resective and ablative epilepsy surgery, these neuromodulatory techniques represent palliative procedures resulting in seizure reduction at best, and seizure-free outcome only in exceptional cases. A recent review found low- to moderate-quality evidence for the efficacy and safety of VNS, DBS, and $\mathrm{RNS}^{161}$. Head-to-head comparisons between different neuromodulatory techniques are missing and, owing to methodological difficulties, most probably will not be available in the near future ${ }^{161}$. Therefore, at present, it is not possible to decide which treatment modality is best suited for a specific patient population and thereby allow personalized treatment decisions.

\section{Conclusions}

Epilepsy surgery represents a valuable treatment options for 10 to $50 \%$ of patients with drug-resistant epilepsy. The most common histopathological findings in epilepsy surgery specimens are hippocampal sclerosis in adults and focal cortical dysplasia in children. Whereas presurgical evaluations and surgeries in patients with mesial temporal sclerosis and benign tumors recently decreased in most centers, non-lesional patients, patients requiring intracranial recordings, and neocortical resections increased. More evaluated patients did not undergo surgery since patients were not suitable for surgery (due mainly to missing identification of a circumscribed epileptogenic zone) or since more patients offered surgery by physicians opted against surgery.

The prerequisite for successful epilepsy surgery is a thorough presurgical evaluation clearly defining epileptogenic and essential brain areas and designing a resection plan in each individual patient. Phase 1 presurgical investigations include high-resolution MRI, video scalp EEG, and detailed neuropsychological assessment. If these investigations yield inconclusive or ambiguous results, additional non-invasive techniques can be used. If the epileptogenic zone cannot be localized with sufficient certainty with non-invasive techniques and the patient is still considered a reasonable surgical candidate, intracranial recordings with depth or subdural electrodes (or both) can be applied during a so-called phase 2 evaluation.

Recent developments in neurophysiological techniques (highdensity EEG, MEG, ESI and MSI, EEG-fMRI, and recording of pHFOs), structural MRI (ultra-high-field imaging at 7 Tesla, novel imaging acquisition protocols, and advanced image analysis [post-processing] techniques), functional imaging (PET and SPECT co-registered to MRI), and fMRI significantly improved non-invasive presurgical evaluation and have opened the option of epilepsy surgery to patients previously not considered surgical candidates.

Technical improvements of resective surgery techniques facilitate successful and safe operations in highly delicate brain areas like the perisylvian area in operculoinsular epilepsy. Novel less-invasive surgical techniques include stereotactic radiosurgery, MgLiTT, and SEEG-guided RFTC.

\section{Abbreviations}

3D, three-dimensional; AAN, American Academy of Neurology; CEEG, extraoperative intracranial electroencephalography through open craniotomy; CSF, cerebrospinal fluid; DBS, deep brain stimulation; DTI, diffusion tensor imaging; ECoG, intraoperative electrocorticography; EEG, electroencephalography; EEG-fMRI, electroencephalography-functional magnetic resonance imaging; ESI, electrical source imaging; ETLE, extratemporal lobe epilepsy; FDG, 18F-fluoro-deoxyglucose; FLAIR, fluid-attenuated inversion recovery; fMRI, functional magnetic 
resonance imaging; HD-EEG, high-resolution electroencephalography; IEEG, intracranial electroencephalography; MEG, magnetoencephalography; MgLiTT, magnetic resonanceguided laser interstitial thermal therapy; MR, magnetic resonance; MRI, magnetic resonance imaging; MSI, magnetic source imaging; MTLE, mesial temporal lobe epilepsy; PET, positron emission tomography; pHFO, pathological high-frequency oscillations; rCBF, regional cerebral blood flow; RNS, responsive neurostimulation; SEEG, stereotactic intracerebral electroencephalography; SEEG-guided RFTC, stereotactic intracerebral electroencephalography-guided radiofrequency thermocoagulation; SISCOM, subtraction single-photon emission computed tomography co-registered to magnetic resonance imaging; SPECT, single-photon emission computed tomography; STATISCOM, statistical ictal single-photon emission computed tomography co-registered to magnetic resonance imaging; SVR, support vector regression; TLE, temporal lobe epilepsy; VNS, vagus nerve stimulation
1. Bell GS, Neligan A, Sander JW: An unknown quantity--the worldwide prevalence of epilepsy. Epilepsia. 2014; 55(7): 958-62. PubMed Abstract | Publisher Full Text

2. Zack MM, Kobau R: National and State Estimates of the Numbers of Adults and Children with Active Epilepsy - United States, 2015. MMWR Morb Mortal Wkly Rep. 2017; 66(31): 821-5.

PubMed Abstract | Publisher Full Text | Free Full Text

3. Jobst $\mathrm{BC}$, Cascino GD: Resective epilepsy surgery for drug-resistant focal epilepsy: a review. JAMA. 2015; 313(3): 285-93. PubMed Abstract | Publisher Full Text

4. Engel J Jr: The current place of epilepsy surgery. Curr Opin Neurol. 2018; 31(2): $192-7$.

PubMed Abstract | Publisher Full Text | Free Full Text

5. Wiebe S, Blume WT, Girvin JP, et al:: A randomized, controlled trial of surgery for temporal-lobe epilepsy. N Engl J Med. 2001; 345(5): 311-8. PubMed Abstract | Publisher Full Text

6. $\quad \mathrm{F}$ Engel J Jr, McDermott MP, Wiebe S, et al.: Early surgical therapy for drugresistant temporal lobe epilepsy: a randomized trial. JAMA. 2012; 307(9): 922-30.

PubMed Abstract | Publisher Full Text | Free Full Text | F1000 Recommendation

7. F Dwivedi R, Ramanujam B, Chandra PS, et al:: Surgery for Drug-Resistant Epilepsy in Children. N Engl J Med. 2017; 377(17): 1639-47. PubMed Abstract | Publisher Full Text | F1000 Recommendation

8. Ryvlin $\mathrm{P}$, Cross $\mathrm{JH}$, Rheims $\mathrm{S}$ : Epilepsy surgery in children and adults. Lancet Neurol. 2014; 13(11): 1114-26.

PubMed Abstract | Publisher Full Text

9. Rathore $\mathrm{C}$, Radhakrishnan K: Concept of epilepsy surgery and presurgical evaluation. Epileptic Disord. 2015; 17(1): 19-31; quiz 31. PubMed Abstract | Publisher Full Text

10. F Vakharia VN, Duncan JS, Witt J-A, et al: Getting the best outcomes from epilepsy surgery. Ann Neurol. 2018; 83(4): 676-90. PubMed Abstract | Publisher Full Text | Free Full Text | F1000 Recommendation

11. F Blumcke I, Spreafico R, Haaker G, et al:: Histopathological Findings in Brain Tissue Obtained during Epilepsy Surgery. N Engl J Med. 2017; 377(17) 1648-56.

PubMed Abstract | Publisher Full Text | F1000 Recommendation

12. F Englot DJ, Ouyang D, Garcia PA, et al:: Epilepsy surgery trends in the United States, 1990-2008. Neurology. 2012; 78(16): 1200-6.

PubMed Abstract | Publisher Full Text | Free Full Text | F1000 Recommendation

13. Bien CG, Raabe AL, Schramm J, et al:: Trends in presurgical evaluation and surgical treatment of epilepsy at one centre from 1988-2009. J Neurol Neurosurg Psychiatr. 2013; 84(1): 54-61. PubMed Abstract | Publisher Full Text

14. Neligan A, Haliasos N, Pettorini B, et al.: A survey of adult and pediatric epilepsy surgery in the United Kingdom. Epilepsia. 2013; 54(5): e62-e65. PubMed Abstract | Publisher Full Text

15. Helmstaedter C, May TW, von Lehe M, et al:: Temporal lobe surgery in Germany from 1988 to 2008: diverse trends in etiological subgroups. Eur J Neurol. 2014; 21(6): 827-34.

PubMed Abstract | Publisher Full Text

16. Jehi $\mathrm{L}$, Friedman $\mathrm{D}$, Carlson $\mathrm{C}$, et al.: The evolution of epilepsy surgery between 1991 and 2011 in nine major epilepsy centers across the United States, Germany, and Australia. Epilepsia. 2015; 56(10): 1526-33. PubMed Abstract | Publisher Full Text | Free Full Text

17. Kaiboriboon K, Malkhachroum AM, Zrik A, et al.: Epilepsy surgery in the United States: Analysis of data from the National Association of Epilepsy Centers.
Epilepsy Res. 2015; 116: 105-9.

PubMed Abstract | Publisher Full Text

18. Cloppenborg T, May TW, Blümcke I, et al.: Trends in epilepsy surgery: stable surgical numbers despite increasing presurgical volumes. J Neurol Neurosurg Psychiatr. 2016; 87(12): 1322-9.

PubMed Abstract | Publisher Full Text

19. F Dugan $\mathrm{P}$, Carlson C, Jetté N, et al.: Derivation and initial validation of a surgical grading scale for the preliminary evaluation of adult patients with drug-resistant focal epilepsy. Epilepsia. 2017; 58(5): 792-800.

PubMed Abstract | Publisher Full Text | F1000 Recommendation

20. Butler TA, Dugan $P$, French $\mathrm{J}$ : Why is mesial temporal lobe epilepsy with Ammon's horn sclerosis becoming less common? Eur J Neurol. 2015; 22(1) e12. PubMed Abstract | Publisher Full Text

21. French J, Friedman $D$ : The evolving landscape of epilepsy neuropathology. Lancet Neurol. 2018; 17(3): 202-3. PubMed Abstract | Publisher Full Text

22. Gross RE, Stern MA, Willie JT, et al:: Stereotactic laser amygdalohippocampotomy for mesial temporal lobe epilepsy. Ann Neurol. 2018; 83(3): 575-87. PubMed Abstract | Publisher Full Text | Free Full Text

23. Baumgartner C, Pirker S: Presurgical evaluation in adults: noninvasive. Handb Clin Neurol. 2012; 108: 841-866.

PubMed Abstract | Publisher Full Text

24. Baumgartner $\mathrm{C}$, Lehner-Baumgartner $\mathrm{E}$ : The functional deficit zone - general principles. In: Lüders HO (ed) Textbook of Epilepsy Surgery. Informa Healthcare, London, 2008; 781-791. Reference Source

25. F Baroumand AG, van Mierlo P, Strobbe G, et al:: Automated EEG source imaging: A retrospective, blinded clinical validation study. Clin Neurophysio. imaging: A retrospective, 2018; 129(11): 2403-10.

PubMed Abstract | Publisher Full Text | F1000 Recommendation

26. Jayakar P, Gotman J, Harvey AS, et al:: Diagnostic utility of invasive EEG fo epilepsy surgery: Indications, modalities, and techniques. Epilepsia. 2016: 57(11): 1735-47.

PubMed Abstract | Publisher Full Text

27. Baumgartner $\mathrm{C}$, Pataraia $\mathrm{E}$, Lindinger $\mathrm{G}$, et al:: Magnetoencephalography in focal epilepsy. Epilepsia. 2000; 41 Suppl 3: S39-47. PubMed Abstract | Publisher Full Text

28. Baumgartner $\mathrm{C}$, Pataraia $\mathrm{E}$ : Revisiting the role of magnetoencephalography in epilepsy. Curr Opin Neurol. 2006; 19(2): 181-6. PubMed Abstract | Publisher Full Text

29. Lantz G, Grave de Peralta R, Spinelli L, et al:: Epileptic source localization with high density EEG: How many electrodes are needed? Clin Neurophysiol. 2003 114(1): 63-9.

PubMed Abstract | Publisher Full Text

30. Song J, Davey C, Poulsen C, et al:: EEG source localization: Sensor density and head surface coverage. J Neurosci Methods. 2015; 256: 9-21. PubMed Abstract | Publisher Full Text

31. Seeck $M$, Koessler $L$, Bast $T$, et al.: The standardized EEG electrode array of the IFCN. Clin Neurophysiol. 2017; 128(10): 2070-7. PubMed Abstract | Publisher Full Text

32. Brodbeck V, Spinelli L, Lascano AM, et al: Electrical source imaging for presurgical focus localization in epilepsy patients with normal MRI. Epilepsia. 2010; 51(4): 583-91. PubMed Abstract | Publisher Full Text

33. Mégevand P, Seeck M: Electroencephalography, magnetoencephalography and source localization: Their value in epilepsy. Curr Opin Neurol. 2018; 31(2) 
$176-83$

PubMed Abstract | Publisher Full Text

34. F Lascano AM, Perneger T, Vulliemoz S, et al:: Yield of MRI, high-density electric source imaging (HD-ESI), SPECT and PET in epilepsy surgery candidates. Clin Neurophysiol. 2016; 127(1): 150-5. PubMed Abstract | Publisher Full Text | F1000 Recommendation

35. Agirre-Arrizubieta Z, Huiskamp GJ, Ferrier $\mathrm{CH}$, et al.: Interictal magnetoencephalography and the irritative zone in the electrocorticogram. Brain. 2009; 132(Pt 11): 3060-71.

PubMed Abstract | Publisher Full Text

36. F Juárez-Martinez EL, Nissen IA, Idema S, et al:: Virtual localization of the seizure onset zone: Using non-invasive MEG virtual electrodes at stereo-EEG electrode locations in refractory epilepsy patients. Neuroimage Clin. 2018; 19: 758-66.

PubMed Abstract | Publisher Full Text | Free Full Text | F1000 Recommendation

37. Grouiller F, Thornton RC, Groening K, et al:: With or without spikes: Localization of focal epileptic activity by simultaneous electroencephalography and functional magnetic resonance imaging. Brain. 2011; 134(Pt 10): 2867-86. PubMed Abstract | Publisher Full Text | Free Full Text

38. F Centeno M, Tierney TM, Perani S, et al:: Combined electroencephalographyfunctional magnetic resonance imaging and electrical source imaging improves localization of pediatric focal epilepsy. Ann Neurol. 2017; 82(2): 278-87.

PubMed Abstract | Publisher Full Text | F1000 Recommendation

39. Jung J, Bouet R, Delpuech C, et al.: The value of magnetoencephalography for seizure-onset zone localization in magnetic resonance imaging-negative partial epilepsy. Brain. 2013; 136(Pt 10): 3176-86.

PubMed Abstract | Publisher Full Text | Free Full Text

40. Knowlton RC, Razdan SN, Limdi N, et al:: Effect of epilepsy magnetic source imaging on intracranial electrode placement. Ann Neurol. 2009; 65(6): 716-23. PubMed Abstract | Publisher Full Text | Free Full Text

41. Thornton R, Vulliemoz S, Rodionov R, et al: Epileptic networks in focal cortical dysplasia revealed using electroencephalography-functional magnetic resonance imaging. Ann Neurol. 2011; 70(5): 822-37.

PubMed Abstract | Publisher Full Text | Free Full Text

42. Koren J, Gritsch G, Pirker S, et al:: Automatic ictal onset source localization in presurgical epilepsy evaluation. Clin Neurophysiol. 2018; 129(6): 1291-9. PubMed Abstract | Publisher Full Tex

43. Nemtsas $P$, Birot G, Pittau F, et al:: Source localization of ictal epileptic activity based on high-density scalp EEG data. Epilepsia. 2017; 58(6): 1027-36. PubMed Abstract | Publisher Full Text

44. Staljanssens W, Strobbe G, Van Holen R, et al.: EEG source connectivity to localize the seizure onset zone in patients with drug resistant epilepsy. Neuroimage Clin. 2017; 16: 689-98.

PubMed Abstract | Publisher Full Text | Free Full Text

45. Staljanssens W, Strobbe G, Holen RV, et al.: Seizure Onset Zone Localization from Ictal High-Density EEG in Refractory Focal Epilepsy. Brain Topogr. 2017; 30(2): 257-71.

PubMed Abstract | Publisher Full Text

46. Beniczky S, Lantz G, Rosenzweig I, et al:: Source localization of rhythmic ictal EEG activity: a study of diagnostic accuracy following STARD criteria. Epilepsia. 2013; 54(10): 1743-52.

PubMed Abstract | Publisher Full Text

47. Beniczky S, Rosenzweig I, Scherg M, et al:: Ictal EEG source imaging in presurgical evaluation: High agreement between analysis methods. Seizure. 2016; 43: 1-5.

PubMed Abstract | Publisher Full Text | Free Full Text

48. Sharma P, Scherg M, Pinborg LH, et al.: Ictal and interictal electric source imaging in pre-surgical evaluation: a prospective study. Eur J Neurol. 2018; 25(9): 1154-60.

PubMed Abstract | Publisher Full Text

49. Habib MA, Ibrahim F, Mohktar MS, et al.: Ictal EEG Source Imaging for Presurgical Evaluation of Refractory Focal Epilepsy. World Neurosurg. 2016; 88: $576-85$.

PubMed Abstract | Publisher Full Text

50. Kuo CC, Tucker DM, Luu P, et al.: EEG source imaging of epileptic activity at seizure onset. Epilepsy Res. 2018; 146: 160-71. PubMed Abstract | Publisher Full Text

51. F Ramanujam B, Bharti K, Viswanathan V, et al:: Can ictal-MEG obviate the need for phase II monitoring in people with drug-refractory epilepsy? A prospective observational study. Seizure. 2017; 45: 17-23. PubMed Abstract | Publisher Full Text | F1000 Recommendation

52. Pellegrino G, Hedrich T, Chowdhury R, et al:: Source localization of the seizure onset zone from ictal EEG/MEG data. Hum Brain Mapp. 2016; 37(7): 2528-46. PubMed Abstract | Publisher Full Text

53. Badier JM, Bénar CG, Woodman M, et al.: Ictal Magnetic Source Imaging in Presurgical Assessment. Brain Topogr. 2016; 29(1): 182-92. PubMed Abstract | Publisher Full Text

54. Jeong W, Kim JS, Chung CK: Usefulness of multiple frequency band source localizations in ictal MEG. Clin Neurophysiol. 2016; 127(2): 1049-56. PubMed Abstract | Publisher Full Text

55. Bragin A, Engel J Jr, Wilson CL, et al.: Hippocampal and entorhinal cortex high- frequency oscillations (100--500 Hz) in human epileptic brain and in kainic acid--treated rats with chronic seizures. Epilepsia. 1999; 40(2): 127-37. PubMed Abstract | Publisher Full Text

56. Jacobs J, Levan $\mathrm{P}$, Châtillon $\mathrm{CE}$, et al.: High frequency oscillations in intracranial EEGs mark epileptogenicity rather than lesion type. Brain. 2009; 132(Pt 4): 1022-37.

PubMed Abstract | Publisher Full Text | Free Full Text

57. Frauscher B, Bartolomei F, Kobayashi K, et al:: High-frequency oscillations: The state of clinical research. Epilepsia. 2017; 58(8): 1316-29.

PubMed Abstract | Publisher Full Text | Free Full Text

58. Jiruska P, Alvarado-Rojas C, Schevon CA, et al.: Update on the mechanisms and roles of high-frequency oscillations in seizures and epileptic disorders. Epilepsia. 2017; 58(8): 1330-9.

PubMed Abstract | Publisher Full Text | Free Full Text

59. Kobayashi K, Watanabe $\mathrm{Y}$, Inoue $\mathrm{T}$, et al:: Scalp-recorded high-frequency oscillations in childhood sleep-induced electrical status epilepticus. Epilepsia. 2010; 51(10): 2190-4.

PubMed Abstract | Publisher Full Text

60. Andrade-Valenca LP, Dubeau F, Mari F, et al:: Interictal scalp fast oscillations as a marker of the seizure onset zone. Neurology. 2011; 77(6): 524-31. PubMed Abstract | Publisher Full Text | Free Full Text

61. van Klink N, Hillebrand A, Zijlmans M: Identification of epileptic high frequency oscillations in the time domain by using MEG beamformer-based virtual sensors. Clin Neurophysiol. 2016; 127(1): 197-208.

PubMed Abstract | Publisher Full Text

62. von Ellenrieder N, Pellegrino G, Hedrich T, et al.: Detection and Magnetic Source Imaging of Fast Oscillations $(40-160 \mathrm{~Hz})$ Recorded with Magnetoencephalography in Focal Epilepsy Patients. Brain Topogr. 2016; 29(2): 218-31.

PubMed Abstract | Publisher Full Text | Free Full Text

63. Jacobs J, Zijlmans M, Zelmann R, et al:: High-frequency electroencephalographic oscillations correlate with outcome of epilepsy surgery. Ann Neurol. 2010; 67(2): 209-20.

PubMed Abstract | Publisher Full Text | Free Full Text

64. Wu JY, Sankar R, Lerner JT, et al:: Removing interictal fast ripples on electrocorticography linked with seizure freedom in children. Neurology. 2010; 75(19): 1686-94.

PubMed Abstract | Publisher Full Text | Free Full Text

65. Höller Y, Kutil R, Klaffenböck L, et al.: High-frequency oscillations in epilepsy and surgical outcome. A meta-analysis. Front Hum Neurosci. 2015; 9: 574. PubMed Abstract | Publisher Full Text | Free Full Text

66. F van 't Klooster MA, van Klink NEC, Zweiphenning WJEM, et al:: Tailoring epilepsy surgery with fast ripples in the intraoperative electrocorticogram. Ann Neurol. 2017; 81(5): 664-76.

PubMed Abstract | Publisher Full Text | F1000 Recommendation

67. F Roehri N, Pizzo F, Lagarde S, et al.: High-frequency oscillations are not better biomarkers of epileptogenic tissues than spikes. Ann Neurol. 2018; 83(1): 84-97.

PubMed Abstract | Publisher Full Text | F1000 Recommendation

68. Conner CR, Ellmore TM, DiSano MA, et al:: Anatomic and electro-physiologic connectivity of the language system: a combined DTI-CCEP study. Comput Biol Med. 2011; 41(12): 1100-9.

PubMed Abstract | Publisher Full Text | Free Full Text

69. F Crowther LJ, Brunner P, Kapeller C, et al:: A quantitative method for evaluating cortical responses to electrical stimulation. $J$ Neurosci Methods. 2019; 311: 67-75.

PubMed Abstract | Publisher Full Text | Free Full Text | F1000 Recommendation

70. Mouthaan BE, van 't Klooster MA, Keizer D, et al.: Single Pulse Electrical Stimulation to identify epileptogenic cortex: Clinical information obtained from early evoked responses. Clin Neurophysiol. 2016; 127(2): 1088-98. PubMed Abstract | Publisher Full Text

71. Boulogne $S$, Ryvlin $P$, Rheims S: Single and paired-pulse electrical stimulation during invasive EEG recordings. Rev Neurol (Paris). 2016; 172(3): 174-81. PubMled Abstract | Publisher Full Text

72. $F$ Matsumoto $R$, Kunieda $T$, Nair D: Single pulse electrical stimulation to probe functional and pathological connectivity in epilepsy. Seizure. 2017; 44: 27-36. PubMed Abstract | Publisher Full Text | Free Full Text | F1000 Recommendation

73. Duncan JS, Winston GP, Koepp MJ, et al: Brain imaging in the assessment for epilepsy surgery. Lancet Neurol. 2016; 15(4): 420-33.

PubMed Abstract | Publisher Full Text | Free Full Text

74. Sidhu MK, Duncan JS, Sander JW: Neuroimaging in epilepsy. Curr Opin Neurol. 2018; 31(4): 371-8.

PubMed Abstract | Publisher Full Tex

75. Rüber T, David B, Elger CE: MRI in epilepsy: clinical standard and evolution. Curr Opin Neurol. 2018; 31(2): 223-31.

PubMed Abstract| Publisher Full Text

76. Téllez-Zenteno JF, Hernández Ronquillo L, Moien-Afshari F, et al.: Surgical outcomes in lesional and non-lesional epilepsy: a systematic review and metaanalysis. Epilepsy Res. 2010; 89(2-3): 310-8. PubMed Abstract | Publisher Full Tex

77. F de Tisi J, Bell GS, Peacock JL, et al:: The long-term outcome of adult epilepsy surgery, patterns of seizure remission, and relapse: a cohort study. 
Lancet. 2011; 378(9800): 1388-95.

PubMed Abstract | Publisher Full Text | F1000 Recommendation

78. Bien CG, Szinay M, Wagner J, et al.: Characteristics and surgical outcomes of patients with refractory magnetic resonance imaging-negative epilepsies. Arch Neurol. 2009; 66(12): 1491-9.

PubMed Abstract | Publisher Full Text

79. Duncan JS: Imaging in the surgical treatment of epilepsy. Nat Rev Neurol. 2010 6(10): 537-50.

PubMed Abstract | Publisher Full Text

80. Wellmer J, Quesada CM, Rothe L, et al.: Proposal for a magnetic resonance imaging protocol for the detection of epileptogenic lesions at early outpatient stages. Epilepsia. 2013; 54(11): 1977-87. PubMed Abstract | Publisher Full Text

81. Stefanits H, Springer E, Pataraia E, et al.: Seven-Tesla MRI of Hippocampal Sclerosis: An In Vivo Feasibility Study With Histological Correlations. Invest Radiol. 2017; 52(11): 666-71.

PubMed Abstract | Publisher Full Text

82. De Ciantis A, Barba C, Tassi L, et al.: 7T MRI in focal epilepsy with unrevealing conventional field strength imaging. Epilepsia. 2016; 57(3): 445-54. PubMed Abstract | Publisher Full Text

83. Wychowski T, Hussain A, Tivarus ME, et al:: Qualitative analysis of double inversion recovery MRI in drug-resistant epilepsy. Epilepsy Res. 2016; 127 195-9.

PubMed Abstract | Publisher Full Text

84. Boscolo Galazzo I, Mattoli MV, Pizzini FB, et al.: Cerebral metabolism and perfusion in MR-negative individuals with refractory focal epilepsy assessed by simultaneous acquisition of ${ }^{18} \mathrm{~F}$-FDG PET and arterial spin labeling. Neuroimage Clin. 2016; 11: 648-57.

PubMed Abstract | Publisher Full Text | Free Full Text

85. Winston GP, Micallef C, Symms MR, et al:: Advanced diffusion imaging sequences could aid assessing patients with focal cortical dysplasia and epilepsy. Epilepsy Res. 2014; 108(2): 336-9.

PubMed Abstract | Publisher Full Text | Free Full Text

86. Huppertz HJ, Kurthen M, Kassubek J: Voxel-based 3D MRI analysis for the detection of epileptogenic lesions at single subject level. Epilepsia. 2009; 50(1): $155-6$.

PubMed Abstract | Publisher Full Text

87. Focke NK, Bonelli SB, Yogarajah M, et al.: Automated normalized FLAIR imaging in MRI-negative patients with refractory focal epilepsy. Epilepsia. 2009; 50(6): 1484-90.

PubMed Abstract | Publisher Full Text

88. Wagner $\mathrm{J}$, Weber $\mathrm{B}$, Urbach $\mathrm{H}$, et al:: Morphometric MRI analysis improves detection of focal cortical dysplasia type II. Brain. 2011; 134(Pt 10): 2844-54. PubMed Abstract | Publisher Full Text

89. Hong SJ, Kim H, Schrader D, et al.: Automated detection of cortical dysplasia type II in MRI-negative epilepsy. Neurology. 2014: 83(1): 48-55. PubMed Abstract | Publisher Full Text | Free Full Text

90. Martin P, Bender B, Focke NK: Post-processing of structural MRI for individualized diagnostics. Quant Imaging Med Surg. 2015; 5(2): 188-203. PubMed Abstract | Publisher Full Text | Free Full Text

91. Lai C, Guo S, Cheng L, et al:: A Comparative Study of Feature Selection Methods for the Discriminative Analysis of Temporal Lobe Epilepsy. Front Neurol. 2017; 8: 633.

PubMed Abstract | Publisher Full Text | Free Full Text

92. $\mathrm{F}$ Martin $\mathrm{P}$, Winston GP, Bartlett $\mathrm{P}$, et al:: Voxel-based magnetic resonance image postprocessing in epilepsy. Epilepsia. 2017; 58(9): 1653-64. PubMed Abstract | Publisher Full Text | Free Full Text | F1000 Recommendation

93. F Wong-Kisiel LC, Tovar Quiroga DF, Kenney-Jung DL, et al:: Morphometric analysis on T1-weighted MRI complements visual MRI review in focal cortical dysplasia. Epilepsy Res. 2018; 140: 184-91. PubMed Abstract | Publisher Full Text | F1000 Recommendation

94. F Kotikalapudi R, Martin P, Marquetand J, et al.: Systematic Assessment of Multispectral Voxel-Based Morphometry in Previously MRI-Negative Foca Epilepsy. AJNR Am J Neuroradiol. 2018; 39(11): 2014-21. PubMed Abstract | Publisher Full Text | F1000 Recommendation

95. Helmstaedter C, Witt JA: Clinical neuropsychology in epilepsy: theoretical and practical issues. Handb Clin Neurol. 2012; 107: 437-459. PubMed Abstract | Publisher Full Text

96. Baxendale S, Thompson P: Beyond localization: the role of traditiona neuropsychological tests in an age of imaging. Epilepsia. 2010; 51(11): 2225-30. PubMed Abstract | Publisher Full Text

97. Hermann B, Loring DW, Wilson S: Paradigm Shifts in the Neuropsychology of Epilepsy. J Int Neuropsychol Soc. 2017; 23(9-10): 791-805. PubMed Abstract | Publisher Full Text | Free Full Text

98. Witt JA, Hoppe C, Helmstaedter C: Neuropsychologist's (re-)view: Resective versus ablative amygdalohippocampectomies. Epilepsy Res. 2018; 142: 161-6. PubMed Abstract | Publisher Full Text

99. Helmstaedter C, Elger CE, Witt JA: The effect of quantitative and qualitative antiepileptic drug changes on cognitive recovery after epilepsy surgery. Seizure. 2016; 36: 63-9.

PubMed Abstract | Publisher Full Text

100. Helmstaedter C, Witt JA: How neuropsychology can improve the care of individual patients with epilepsy. Looking back and into the future. Seizure. 2017; 44: 113-20.

PubMed Abstract | Publisher Full Text

101. Andersson-Roswall L, Engman E, Samuelsson H, et al:: Cognitive outcome 10 years after temporal lobe epilepsy surgery: a prospective controlled study. Neurology. 2010; 74(24): 1977-85.

PubMed Abstract | Publisher Full Text

102. Andersson-Roswall L, Malmgren $\mathrm{K}$, Engman $\mathrm{E}$, et al.: Verbal memory decline is less frequent at 10 years than at 2 years after temporal lobe surgery for epilepsy. Epilepsy Behav. 2012; 24(4): 462-7. PubMed Abstract | Publisher Full Text

103. Witt JA, Helmstaedter C: Cognition in epilepsy: current clinical issues of interest. Curr Opin Neurol. 2017; 30(2): 174-9. PubMed Abstract | Publisher Full Text

104. Helmstaedter C: Cognitive outcomes of different surgical approaches in temporal lobe epilepsy. Epileptic Disord. 2013; 15(3): 221-39.

PubMed Abstract | Publisher Full Text

105. Baxendale S, Wilson SJ, Baker GA, et al:: Indications and expectations for neuropsychological assessment in epilepsy surgery in children and adults. Epileptic Disord. 2019; 21(3): 221-34. PubMed Abstract

106. Baxendale S, Wilson SJ, Baker GA, et al.: Indications and expectations for neuropsychological assessment in epilepsy surgery in children and adults: Executive summary of the report of the ILAE Neuropsychology Task Force Diagnostic Methods Commission: 2017-2021. Epilepsia. 2019; 60(9): 1794-6. PubMed Abstract | Publisher Full Text

107. F Drane DL: MRI-Guided stereotactic laser ablation for epilepsy surgery: Promising preliminary results for cognitive outcome. Epilepsy Res. 2018; 142 $170-5$

PubMed Abstract | Publisher Full Text | Free Full Text | F1000 Recommendation

108. Drane DL, Loring DW, Voets NL, et al.: Better object recognition and naming outcome with MRI-guided stereotactic laser amygdalohippocampotomy for temporal lobe epilepsy. Epilepsia. 2015; 56(1): 101-13. PubMed Abstract | Publisher Full Text | Free Full Text

109. Drane DL, Pedersen NP: Knowledge of language function and underlying neural networks gained from focal seizures and epilepsy surgery. Brain Lang. 2019; 189: 20-33.

PubMed Abstract | Publisher Full Text

110. Drane DL, Ojemann JG, Phatak V, et al.: Famous face identification in temporal lobe epilepsy: support for a multimodal integration model of semantic memory. Cortex. 2013; 49(6): 1648-67. PubMed Abstract | Publisher Full Text | Free Full Text

111. von Oertzen TJ: PET and ictal SPECT can be helpful for localizing epileptic foci. Curr Opin Neurol. 2018; 31(2): 184-91. PubMed Abstract | Publisher Full Text | Free Full Text

112. Engel J Jr, Kuhl DE, Phelps ME, et al.: Comparative localization of epileptic foci in partial epilepsy by PCT and EEG. Ann Neurol. 1982; 12(6): 529-37. PubMed Abstract | Publisher Full Text

113. Chassoux F, Artiges E, Semah F, et al.: Determinants of brain metabolism changes in mesial temporal lobe epilepsy. Epilepsia. 2016; 57(6): 907-19. PubMed Abstract | Publisher Full Text

114. Engel J Jr, Thompson PM: Going beyond hippocampocentricity in the concept of mesial temporal lobe epilepsy. Epilepsia. 2012; 53(1): 220-3. PubMed Abstract | Publisher Full Text | Free Full Text

115. F Richardson MP: Large scale brain models of epilepsy: Dynamics meets connectomics. J Neurol Neurosurg Psychiatr. 2012; 83(12): 1238-48. PubMed Abstract | Publisher Full Text | F1000 Recommendation

116. $F$ Chassoux $F$, Artiges $E$, Semah $F$, et al:: ${ }^{18} F-F D G-P E T$ patterns of surgical success and failure in mesial temporal lobe epilepsy. Neurology. 2017; 88(11): 1045-53.

PubMed Abstract | Publisher Full Text | F1000 Recommendation

117. Farooque $\mathrm{P}$, Hirsch L, Levy $\mathrm{S}$, et al.: Surgical outcome in adolescents with mesial temporal sclerosis: Is it different? Epilepsy Behav. 2017; 69: 24-7. PubMed Abstract | Publisher Full Text

118. Immonen A, Jutila L, Muraja-Murro A, et al:: Long-term epilepsy surgery outcomes in patients with MRI-negative temporal lobe epilepsy. Epilepsia. 2010; 51(11): 2260-9.

PubMed Abstract | Publisher Full Text

119. Gok B, Jallo G, Hayeri R, et al:: The evaluation of FDG-PET imaging for epileptogenic focus localization in patients with MRI positive and MRI negative temporal lobe epilepsy. Neuroradiology. 2013; 55(5): 541-50. PubMed Abstract | Publisher Full Text

120. LoPinto-Khoury C, Sperling MR, Skidmore C, et al: Surgical outcome in PETpositive, MRI-negative patients with temporal lobe epilepsy. Epilepsia. 2012; 53(2): 342-8. PubMed Abstract | Publisher Full Text

121. $\mathrm{F}$ Muhlhofer W, Tan YL, Mueller SG, et al.: MRI-negative temporal lobe epilepsy-What do we know? Epilepsia. 2017; 58(5): 727-42. PubMed Abstract | Publisher Full Text | F1000 Recommendation

122. $\mathrm{F}$ Chassoux F, Rodrigo $\mathrm{S}$, Semah F, et al:: FDG-PET improves surgical outcome in negative MRI Taylor-type focal cortical dysplasias. Neurology. 2010; 
75(24): 2168-75

PubMed Abstract | Publisher Full Text | F1000 Recommendation

123. F Desarnaud S, Mellerio $C$, Semah F, et al:: ${ }^{18} \mathrm{~F}-\mathrm{FDG}$ PET in drug-resistant epilepsy due to focal cortical dysplasia type 2: additional value of electroclinical data and coregistration with MRI.. Eur J Nucl Med Mol Imaging. 2018; 45(8): 1449-60.

PubMed Abstract | Publisher Full Text | F1000 Recommendation

124. F Mendes Coelho VC, Morita ME, Amorim BJ, et al:: Automated Online Quantification Method for ${ }^{18}$ F-FDG Positron Emission Tomography/ CT Improves Detection of the Epileptogenic Zone in Patients with Pharmacoresistant Epilepsy. Front Neurol. 2017; 8: 453. PubMed Abstract | Publisher Full Text | Free Full Text | F1000 Recommendation

125. F Tan YL, Kim H, Lee S, et al.: Quantitative surface analysis of combined MR and PET enhances detection of focal cortical dysplasias. Neuroimage. 2018; 166: $10-8$

PubMed Abstract | Publisher Full Text | Free Full Text | F1000 Recommendation

126. O'Brien TJ, So EL, Mullan BP, et al:: Subtraction ictal SPECT co-registered to MRI improves clinical usefulness of SPECT in localizing the surgical seizure focus. Neurology. 1998; 50(2): 445-54.

PubMed Abstract |Publisher Full Tex

127. F Long Z, Hanson DP, Mullan BP, et al.: Analysis of Brain SPECT Images Coregistered with MRI in Patients with Epilepsy: Comparison of Three Methods. J Neuroimaging. 2018; 28(3): 307-12. PubMed Abstract | Publisher Full Text | F1000 Recommendation

128. Kazemi NJ, Worrell GA, Stead SM, et al.: Ictal SPECT statistical parametric mapping in temporal lobe epilepsy surgery. Neurology. 2010; 74(1): 70-6. PubMed Abstract | Publisher Full Text | Free Full Text

129. F Szaflarski JP, Gloss D, Binder JR, et al.: Practice guideline summary: Use of fMRI in the presurgical evaluation of patients with epilepsy: Report of the Guideline Development, Dissemination, and Implementation Subcommittee of the American Academy of Neurology. Neurology. 2017; 88(4): 395-402. PubMed Abstract | Publisher Full Text | Free Full Text | F1000 Recommendation

130. Sabsevitz DS, Swanson SJ, Hammeke TA, et al.: Use of preoperative functional neuroimaging to predict language deficits from epilepsy surgery. Neurology. 2003; 60(11): 1788-92.

PubMed Abstract | Publisher Full Text

131. Bonelli SB, Thompson PJ, Yogarajah M, et al:: Imaging language networks before and after anterior temporal lobe resection: results of a longitudinal fMRI study. Epilepsia. 2012; 53(4): 639-50.

PubMed Abstract | Publisher Full Text | Free Full Text

132. Rosazza C, Ghielmetti F, Minati L, et al.: Preoperative language lateralization in temporal lobe epilepsy (TLE) predicts peri-ictal, pre- and post-operative language performance: An fMRI study. Neuroimage Clin. 2013; 3: 73-83. PubMed Abstract | Publisher Full Text | Free Full Text

133. F Babajani-Feremi A, Holder CM, Narayana S, et al:: Predicting postoperative language outcome using presurgical fMRI, MEG, TMS, and high gamma ECoG. Clin Neurophysiol. 2018; 129(3): 560-71. PubMed Abstract | Publisher Full Text | F1000 Recommendation

134. Mathern GW, Beninsig L, Nehlig A: From the editors: Epilepsia's survey on the necessity of the Wada test and intracranial electrodes for cortical mapping. Epilepsia. 2014; 55(12): 1887-9. PubMed Abstract | Publisher Full Text

135. F Labudda K, Mertens M, Kalbhenn T, et al.: Partial resection of presurgical fMRI activation is associated with a postsurgical loss of language function after frontal lobe epilepsy surgery. Neurocase. 2017; 23(3-4): 239-48. PubMed Abstract | Publisher Full Text | F1000 Recommendation

136. Sidhu MK, Stretton J, Winston GP, et al:: A functional magnetic resonance imaging study mapping the episodic memory encoding network in tempora lobe epilepsy. Brain. 2013; 136(Pt 6): 1868-88. PubMed Abstract | Publisher Full Text | Free Full Text

137. Sidhu MK, Stretton J, Winston GP, et al:: Memory network plasticity after temporal lobe resection: a longitudinal functional imaging study. Brain. 2016; 139(Pt 2): 415-30.

PubMed Abstract | Publisher Full Text | Free Full Text

138. Bonelli SB, Powell RH, Yogarajah M, et al.: Imaging memory in temporal lobe epilepsy: predicting the effects of temporal lobe resection. Brain. 2010 133(Pt 4): 1186-99.

PubMed Abstract | Publisher Full Text | Free Full Text

139. Sidhu MK, Stretton J, Winston GP, et al:: Memory fMRI predicts verbal memory decline after anterior temporal lobe resection. Neurology. 2015; 84(15): 1512-9. PubMed Abstract | Publisher Full Text | Free Full Text

140. F Cabrera OS, Lehéricy S, Masson V, et al:: Adapting a memory fMRI research protocol in clinical routine: Feasibility and results. Epilepsy Behav. 2018; 81: 49-54. PubMed Abstract | Publisher Full Text | F1000 Recommendation

141. Kahane P, Spencer SS: Invasive evaluation. Handb Clin Neurol. 2012; 108
867-879

PubMed Abstract | Publisher Full Text

142. F Bouthillier A, Nguyen DK: Epilepsy Surgeries Requiring an Operculoinsular Cortectomy: Operative Technique and Results. Neurosurgery. 2017; 81(4): 602-612.

PubMed Abstract | Publisher Full Text | F1000 Recommendation

143. Feng ES, Sui CB, Wang TX, et al.: Stereotactic radiosurgery for the treatment of mesial temporal lobe epilepsy. Acta Neurol Scand. 2016; 134(6): 442-51. PubMed Abstract | Publisher Full Text

144. F McGonigal A, Sahgal A, De Salles A, et al:: Radiosurgery for epilepsy: Systematic review and International Stereotactic Radiosurgery Society (ISRS) practice guideline. Epilepsy Res. 2017; 137: 123-31.

PubMed Abstract | Publisher Full Text | F1000 Recommendation

145. Bezchlibnyk YB, Willie JT, Gross RE: A neurosurgeon`s view: Laser interstitial thermal therapy of mesial temporal lobe structures. Epilepsy Res. 2018; 142: 135-9.

PubMed Abstract | Publisher Full Text

146. Kang JY, Sperling MR: Magnetic Resonance Imaging-Guided Laser Interstitia Thermal Therapy for Treatment of Drug-Resistant Epilepsy. Neurotherapeutics. 2017; 14(1): 176-81.

PubMed Abstract | Publisher Full Text | Free Full Text

147. Kang JY, Sperling MR: Epileptologist's view: Laser interstitial thermal ablation for treatment of temporal lobe epilepsy. Epilepsy Res. 2018; 142: 149-52. PubMed Abstract | Publisher Full Text

148. Donos C, Breier J, Friedman E, et al.: Laser ablation for mesial temporal lobe epilepsy: Surgical and cognitive outcomes with and without mesial temporal sclerosis. Epilepsia. 2018; 59(7): 1421-32. PubMed Abstract | Publisher Full Text

149. Le S, Ho AL, Fisher RS, et al:: Laser interstitial thermal therapy (LITT): Seizure outcomes for refractory mesial temporal lobe epilepsy. Epilepsy Behav. 2018; 89: $37-41$.

PubMed Abstract | Publisher Full Text

150. Kang JY, Wu C, Tracy J, et al.: Laser interstitial thermal therapy for medically intractable mesial temporal lobe epilepsy. Epilepsia. 2016; 57(2): 325-34. PubMed Abstract | Publisher Full Text

151. F Curry DJ, Raskin J, Ali I, et al:: MR-guided laser ablation for the treatment of hypothalamic hamartomas. Epilepsy Res. 2018; 142: 131-4. PubMed Abstract | Publisher Full Text | F1000 Recommendation

152. Catenoix $\mathrm{H}$, Bourdillon $\mathrm{P}$, Guénot $\mathrm{M}$, et al:: The combination of stereo-EEG and radiofrequency ablation. Epilepsy Res. 2018; 142: 117-20. PubMed Abstract | Publisher Full Text

153. Cossu M, Fuschillo D, Cardinale F, et al.: Stereo-EEG-guided radio-frequency thermocoagulations of epileptogenic grey-matter nodular heterotopy. $J$ Neurol Neurosurg Psychiatry. 2014; 85: 611-7. PubMed Abstract | Publisher Full Text

154. Cossu M, Fuschillo D, Casaceli G, et al:: Stereoelectroencephalography-guided radiofrequency thermocoagulation in the epileptogenic zone: A retrospective study on 89 cases. J Neurosurg. 2015; 123(6): 1358-67. PubMed Abstract | Publisher Full Text

155. Cossu M, Cardinale F, Casaceli G, et al:: Stereo-EEG-guided radiofrequency thermocoagulations. Epilepsia. 2017; 58: 66-72. PubMed Abstract | Publisher Full Text

156. Cossu M, Mirandola L, Tassi L: RF-ablation in periventricular heterotopia-related epilepsy. Epilepsy Res. 2018; 142: 121-5. PubMed Abstract | Publisher Full Text

157. Dimova P, de Palma L, Job-Chapron AS, et al:: Radiofrequency thermocoagulation of the seizure-onset zone during stereoelectroencephalography. Epilepsia. 2017; 58(3): 381-92. PubMed Abstract | Publisher Full Text

158. Bourdillon $\mathrm{P}$, Isnard $\mathrm{J}$, Catenoix $\mathrm{H}$, et al:: Stereo electroencephalography-guided radiofrequency thermocoagulation (SEEG-guided RF-TC) in drug-resistant focal epilepsy: Results from a 10-year experience. Epilepsia. 2017; 58(1): 85-93. PubMed Abstract | Publisher Full Text

159. F Bourdillon $\mathrm{P}$, Cucherat M, Isnard J, et al.: Stereo-electroencephalographyguided radiofrequency thermocoagulation in patients with focal epilepsy: A systematic review and meta-analysis. Epilepsia. 2018; 59(12): 2296-304. PubMed Abstract | Publisher Full Text | F1000 Recommendation

160. Bourdillon $P$, Devaux $B$, Job-Chapron AS, et al.: SEEG-guided radiofrequency thermocoagulation. Neurophysiol Clin. 2018; 48(1): 59-64.

PubMed Abstract | Publisher Full Text

161. F Boon P, De Cock E, Mertens A, et al:: Neurostimulation for drug-resistant epilepsy: A systematic review of clinical evidence for efficacy, safety, contraindications and predictors for response. Curr Opin Neurol. 2018; 31(2): 198-210.

PubMed Abstract | Publisher Full Text | F1000 Recommendation 


\section{Open Peer Review}

\section{Current Peer Review Status:}

\section{Editorial Note on the Review Process}

Faculty Reviews are review articles written by the prestigious Members of Faculty Opinions. The articles are commissioned and peer reviewed before publication to ensure that the final, published version is comprehensive and accessible. The reviewers who approved the final version are listed with their names and affiliations.

\section{The reviewers who approved this article are:}

\section{Version 1}

\section{Pieter van Mierlo}

Department of Electronics and Information Systems, Ghent University, Ghent, Belgium

Competing Interests: Pieter van Mierlo is a founder and shareholder of Epilog NV.

\section{Daniel L Drane}

1 Department of Neurology and Pediatrics, Emory University School of Medicine, Atlanta, GA, USA

2 Department of Neurology, University of Washington School of Medicine, Seattle, WA, USA

Competing Interests: No competing interests were disclosed.

The benefits of publishing with F1000Research:

- Your article is published within days, with no editorial bias

- You can publish traditional articles, null/negative results, case reports, data notes and more

- The peer review process is transparent and collaborative

- Your article is indexed in PubMed after passing peer review

- Dedicated customer support at every stage

For pre-submission enquiries, contact research@f1000.com 